\title{
Retraction
}

Mostaf Jalal* and Esmeel Mansouri

\section{Thermal and mechanical characteristics of cement nanocomposites}

https://doi.org/10.1515/secm-2021-0020

received May 05, 2021; accepted May 05, 2021

Retraction of: Mostaf Jalal and Esmeel Mansouri. Thermal and mechanical characteristics of cement nanocomposites. Sci Eng Compos Mater. 2013;21(1):35-40. doi: 10.1515/secm.2012.0053.
This article has been retracted at the request of the Editor-in-Chief, as it contains a large portion of text that have been duplicated from the article: Byung Wan Jo, Chang-Huyn Kim, Ghi-ho Tae, and Jong-bin Park. Characteristics of cement mortar with nano- $\mathrm{SiO}_{2}$ particles. Constr Build Mater. 2007;21(6):1351-5. doi: 10.1016/ j.conbuildmat.2005.12.020.

\footnotetext{
* Corresponding author: Mostaf Jalal, Young Researchers Club and Elites, Science and Research Branch, Islamic Azad University, Tehran, Iran, e-mail: mjalal@aut.ac.ir, m.jalal.civil@gmail.com Esmeel Mansouri: Department of Civil Engineering, Razi University, Kermanshah, Iran
} 